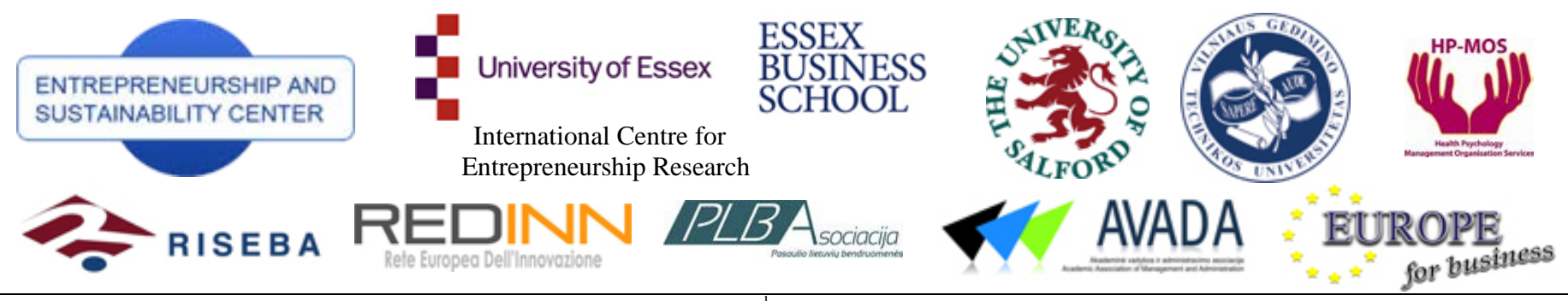

ENTREPRENEURSHIP AND SUSTAINABILITY ISSUES

ISSN 2345-0282 (online) http://jssidoi.org/jesi/

\title{
ENERGY BALANCING ACROSS CITIES: VIRTUAL POWER PLANT PROTOTYPE AND IURBAN CASE STUDIES
}

\author{
Michael Oates ${ }^{1}$, Aidan Meliaํㅜ, Valeria Ferrando ${ }^{1}$ \\ 1, Integrated Environmental Solutions Ltd, Glasgow, G20 0SP, United Kingdom \\ E-mails:1mike.oates@iesve.com
}

Received 23 October 2016; accepted 10 December 2016

\begin{abstract}
This paper summarises Virtual Power Plant (VPP) development within the European Seventh Framework Programme (FP7) project Intelligent URBAn eNergy tool (iURBAN).In the context of this work the VPP is considered as a high level design tool based upon load aggregation of near real-time metered energy demand and generation data at building/apartment levels. Selected data can be aggregated up to city level, or user defined and selected levels such as district, neighbourhood, low voltage electricity network, district heating network etc. Two types of analysis can be performed by the VPP: 'as is' model(s), representing the structures and consumption patterns currently in place (the status quo), and 'what if' (variant) model(s), representing possible alternatives such as adding photovoltaics (PV) at building and/or distribution levels. Target users, city planners and utility companies, will be able to use the VPP to gain an understanding of energy demand/generation at user defined and selected levels of interest ranging from high level city planning to the selection of individual buildings or user defined energy networks and so on. 'What if' scenarios aid in future development and planning of cities.
\end{abstract}

The paper outlines an example VPP case study from the iURBAN project (grant agreement $\mathrm{N}^{\circ} 608712$ ).

Keywords: Virtual Power Plant, City model, ICT tools, High level city planning, distributed energy resources

Reference to this paper should be made as follows: Oates, M., Melia, A., Kerrigan, R., Ferrando, V. 2017. Energy balancing accross cities: Virtual Power Plant prototype and iURBAN case studies, Entrepreneurship and Sustainability Issues, $351-363$ http://dx.doi.org/10.9770/jesi.2017.4.3S(10)

JEL Classifications: C22, C61, C63, C67, C88

Additional disciplines: Computer Science, Mathematics

\footnotetext{
${ }^{1}$ This research was supported by the iURBAN project. Project funding from the European Union's Seventh Programme for research, technological development and demonstration under grant agreement No 608712
}

The article reflects the views only of the authors, and the Commission cannot be held responsible for any use which may be made of the information contained therein. The information in this document is provided as is and no guarantee or warranty is given that the information is fit for any particular purpose. The user thereof uses the information at its sole risk and liability 


\section{Introduction}

There a number of Virtual Power Plant (VPP) (Mostafa, 2017), (Othman, 2015) definitions. Landsbergen (2009) describes a VPP as a system that integrates several types of power sources, (such as micro combined, heat and power (CHP), wind-turbines, small hydro, photovoltaics (PV), back-up generators, batteries etc.) so as to give a reliable overall power supply. Navigant Research (Asmus, 2014) defines a VPP as a system that relies upon software and a smart grid to remotely and automatically dispatch and optimize Distributed Energy Resources (DER)s via an aggregation and optimization platform linking retail to wholesale markets. Due to increased activity in smart meter installations and other smart grid technologies, as well as challenges in balancing variable renewable generation on the grid it is reported that total annual VPP vendor revenue will grow from $\$ 1.1$ billion in 2014 to $\$ 5.3$ billion in 2023 (Navigant Research. 2014).

This paper outlines Virtual Power Plant (VPP) development within the European Seventh Framework Programme (FP7) project Intelligent URBAn eNergy tool (iURBAN) (iURBAN, 2016). In the context of the iURBAN project it was agreed that the VPP should not follow that of detailed network modelling software available on the current market, such as GridLAB-D ${ }^{\mathrm{TM}}$ (GridLAB-D, 2012). The VPP is developed as a high level design tool. And that the modelling approach of the VPP is to be based upon load aggregation of near real-time metered energy demand and generation data and modelling of electricity and heat generation at building/apartment and district level.

Fig.1 gives a simplified overview of the iURBAN Information and communications technology (ICT) architecture, its main focus being on the relationship between the VPP and connected components. The broader overview of the i Fig URBAN ICT architecture includes components that combine to form a Smart Decision Support System (SmartDSS). The SmartDSS consists of; Local Decision Support System graphical user interface (LDSS-GUI), LDSS part of the Smart City Database (SCDB-LDSS), Smart City Prediction Algorithms (SCPA), and meteorological data parsed from Weather Analytics (WA) (Weather Analytics, 2016.). Demand and generation metered data from buildings within the iURBAN demonstrations cities is parsed to the SCDB-LDSS. This data along with meteorological data from WA is parsed to the SCPA. The SCPA component performs analysis on the data and generates forecast demand and generation data up to 72 hours ahead, which is stored in the SCDB-LDSS. Within iURBAN the LDSS-GUI is a tool used by occupants of private buildings, apartments and public municipality buildings such as kindergartens (schools), offices, leisure centres. The LDSS-GUI includes demand response (DR) actions but its primary focus is to educate users on how and where energy is being consumed with a view to encouraging users to make savings, energy and monetary, and reduce greenhouse gas emissions. The work of the LDSS-GUI is not covered in this paper. 


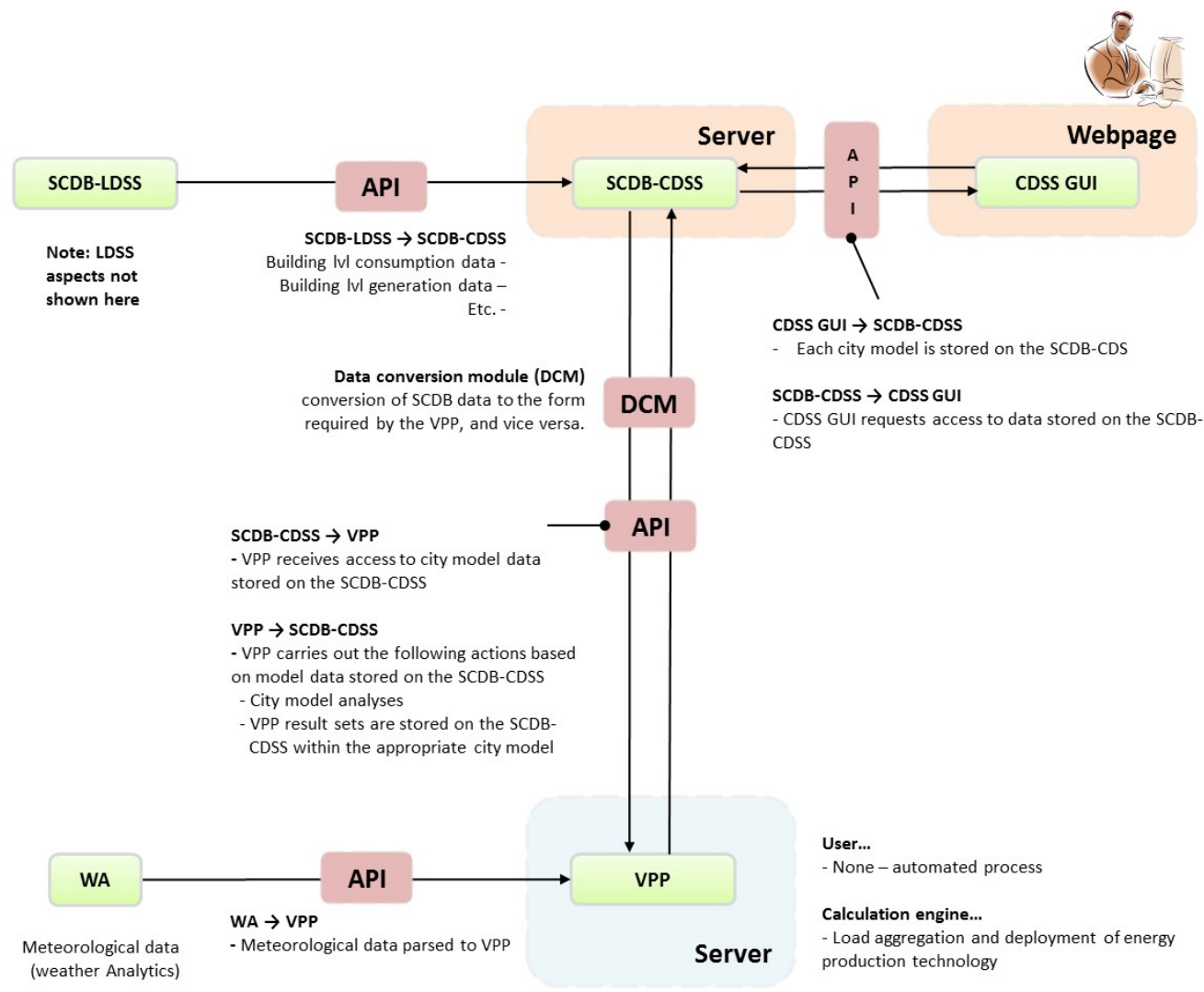

Fig.1. iURBAN ICT architecture - CDSS/VPP relationship diagram

Source: iURBAN, 2016

In addition to the LDSS aspects of the SmartDSS, the Central Decision Support System GUI (CDSS-GUI) is a tool used by utilities and municipalities. The CDSS-GUI enables users to view metered data at a city scale and focused areas of interest such as district and neighbourhood level, to make informed decisions on high level planning. In addition the CDSS-GUI is to act as an interface to the VPP. The VPP, developed by IES (IES Ltd, 2016), is a back-end calculation engine to the CDSS. Via an application programme interface (API) layer the VPP is passed city model data stored on the CDSS part of the Smart City Database (SCDB-CDSS), and writes the results of the calculations back to the SCDB-CDSS for access by the CDSS graphical user interface (GUI). There is also an API that exists between the SCDB-LDSS and the SCDB-CDSS which parses stored metered and forecast data from the SCDB-LDSS to the SCDB-CDSS. The SCDB-CDSS and CDSS-GUI are both developed by the iURBAN partner Vitrociset (Vitrociset, 2016).

\section{VPP modelling approach}

As outlined within Fig.1 the VPP is a component of the iURBAN ICT architecture. The VPP will analyse city models stored on the SCDB-CDSS. Different models may be created for different purposes by the CDSS-GUI user - for example to focus on particular regions of the city, particular types of building, particular energy supply and management technologies, or degrees of modelling detail appropriate to particular tasks. 
City models managed by the CDSS-GUI user may be conceptually divided into two categories: 'as is' city models representing the structures and consumption patterns currently in place (the status quo), and 'what if' city models representing possible alternatives. Examples of 'what if' variant city model(s) include the addition of distributed energy resources (DER), electricity storage, modified demand from buildings and electric vehicles. 'What if' variant model(s) can answer questions such as:

- What is the likely effect of adding PV arrays to certain buildings?

- What is the likely effect of adding electricity storage at a certain point in the electricity distribution network?

- What is the likely effect of introducing a district CHP plant to serve a certain area?

- What is the likely effect of introducing a large-scale PV farm to serve a certain area?

- What is the likely effect of introducing tariffs in monetary and energy consumption terms?

Users of the CDSS-GUI such as city planners and utility companies will be able to undertake VPP analysis to gain an understanding of energy demand and generation and the associated costs at selected levels of interest, ranging from high level city planning to the selection of individual buildings or user defined energy networks.

To avoid ambiguity city model data passed to the VPP is referred to as the VPP city model. The VPP city model is formed around the following features, Commodity, External supply, Commodity account, Fuel, carbon emission $\left(\mathrm{CO}^{2}\right)$ emissions, Distribution network, Network node, Transmission channel, Prosumer object, DER object, Generator, Storage device and manger, which are illustrated in Fig.2.

Fig.2 illustrates an electricity distribution network defined for a city model. In this diagram rectangles with dashed borders represent CDSS-GUI objects, which serve as receptacles for VPP objects. VPP objects fall into three basic categories: nodes (coloured discs), DER objects (colour-filled rectangles) and managers (colour-filled diamonds). DER objects are further categorised according to type such as electricity network; power station, CHP, PV array, wind turbine, electricity storage and heat network; heat generator, electric heat pump, CHP, solar water heating, thermal storage. The filled rectangles at the base of the diagram are prosumer units by means of which demands represented by input Timeseries are connected to the system. Other VPP objects function algorithmically as a function of other variables in the model. 


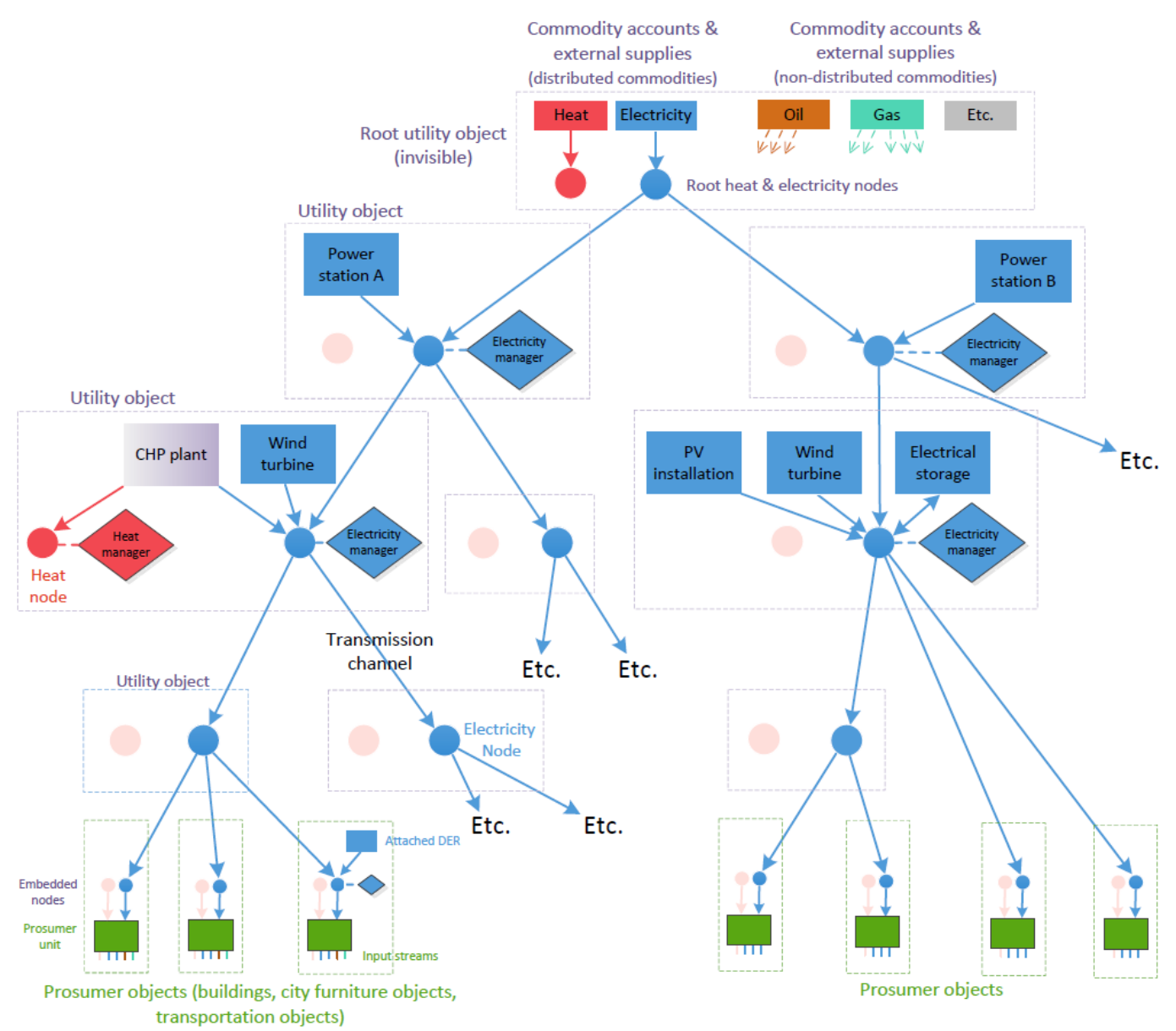

Fig.2. Part of an example city model focusing on the electricity distribution network

Source: iURBAN, 2016

\section{Example case study}

The CDSS-GUI, SCDB-CDSS and VPP development and integration is finalising completion in July 2016. Due to development still taking place within the CDSS-GUI, it is not possible to present a CDSS-GUI network diagram in this paper. Instead a depiction of the iURBAN example case studies is outlined in VPP diagrammatic form. Due to the sensitive nature of participant's details and metered data used within the project, the diagrams refrain from using sensitive details such as building names.

\section{Case study - Rijeka, Croatia}

A CDSS-GUI city view of Rijeka denoting iURBAN metered installations is shown within Fig.3. There are 3 public Kindergartens, 4 public schools, 12 residential, 4 sports centres, 2 culture centres and 7 heating plant installations. Refer to Fig.3 for CDSS-GUI legend notation. 

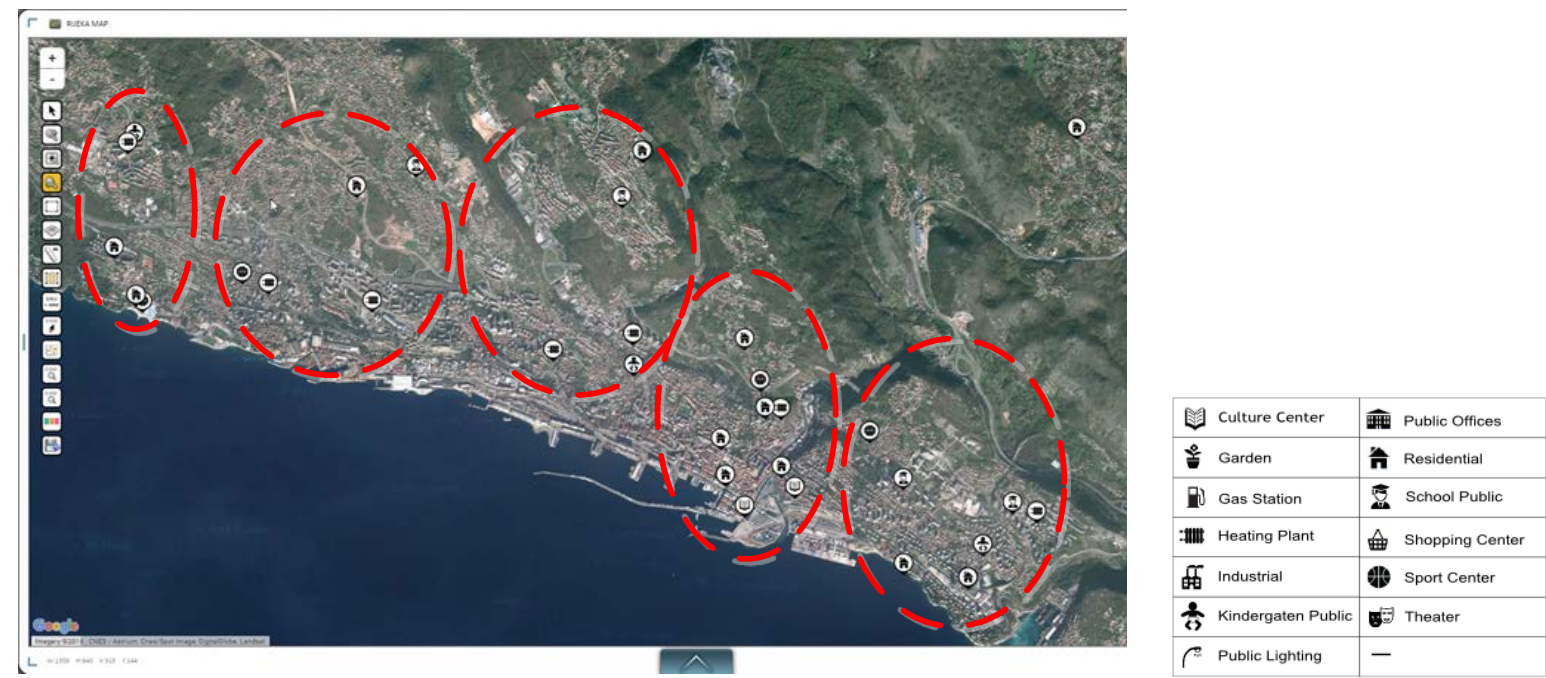

Fig.3. CDSS-GUI - Rijeka, Croatia. Red dashed circles denote defined building clusters and CDSS-GUI legend

Source: Vitrociset, 2016

\section{'As is' scenario}

Fig.4 illustrates a simple VPP electricity network model. 


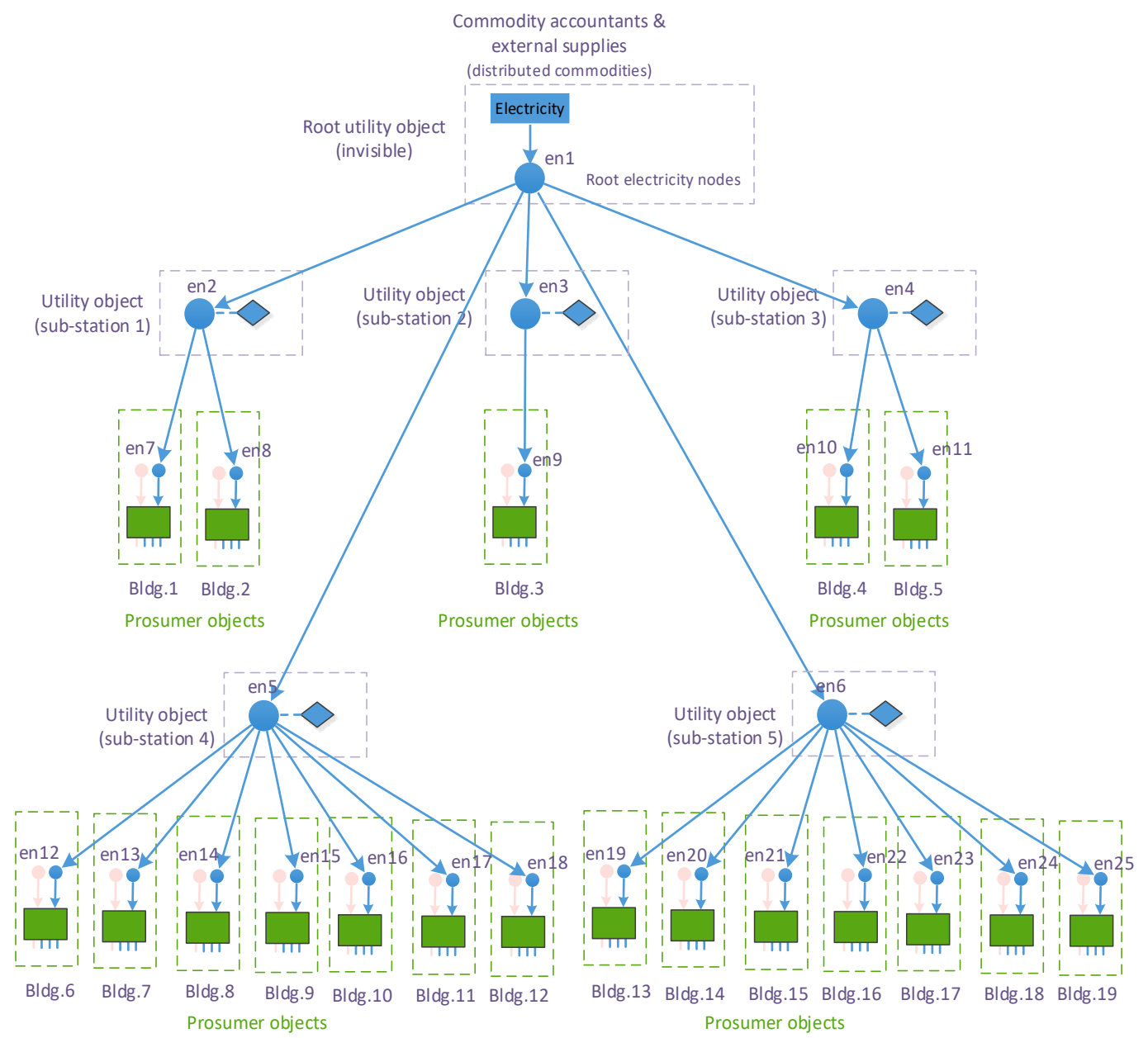

Fig.4. Simple VPP electricity network model - Rijeka, Croatia

Source: Author

Due to the sparse nature of the building locations, limited network topology information and metered installations within the framework of the iURBAN project the Rijeka case study has been simplified, refer to Fig.3. Buildings within close proximity have been grouped together and linked to a utility object representative of a sub-station. 5 sub-stations are shown in Fig.4. In time the network model will be refined as more detail is known about network connections within Rijeka.

Further to sensitivity analysis carried out on the SCDB-CDSS data the below period of analysis is considered for selected meter installations. The period of analysis was selected on the criteria of having the maximum number of meters with non-missing data for 1 whole week.

Data summary:

- Location: Rijeka (CityModelName calls Weather Analytics (WA) API for Rijeka weather data)

- Latitude: N/A (WA API)

- $\quad$ Altitude: N/A (WA API)

- Scenario: As-is - electricity network

- $\quad$ Start date/time:2016-03-01 [00:00] 
- $\quad$ End date/time: 2016-03-07 [23:00]

- Reporting period: Hourly (on the hour)

- Electricity installations devised into 5 hypothetical electricity sub-stations, refer to Fig.3.

Within the iURBAN framework the project does not have access to all utilities, such as electricity, district heating, gas and water, meter readings for each installation. For the electricity network 19 out of 34 building installations have electricity meter readings. Table 1 list building types used within Rijeka case study and denotes available electricity consumption and production meters.

Table 1. Hypothetical electricity sub-stations 1 to 5

\begin{tabular}{|c|c|c|c|c|}
\hline $\begin{array}{l}\text { Hypothetical } \\
\text { Sub-stations }\end{array}$ & $\begin{array}{c}\text { Prosumer object } \\
\text { name }\end{array}$ & Type & $\begin{array}{c}\text { Meter } \\
\text { (Consumption) }\end{array}$ & $\begin{array}{c}\text { Meter } \\
\text { (Production) }\end{array}$ \\
\hline 1 & Building 1 & Public kindergarten & Yes & Yes \\
\hline “ & Building 2 & Sports Centre & Yes & Yes \\
\hline 2 & Building 3 & Public school & Yes & No \\
\hline 3 & Building 4 & Public school & Yes & Yes \\
\hline “ & Building 5 & Public kindergarten & Yes & Yes \\
\hline 4 & Building 6 & Residential & Yes & No \\
\hline “ & Building 7 & Sports Centre & Yes & No \\
\hline “ & Building 8 & Residential & Yes & No \\
\hline “" & Building 9 & Residential & Yes & No \\
\hline “ & Building 10 & Residential & Yes & Yes \\
\hline “ & Building 11 & Culture Centre & Yes & No \\
\hline “ & Building 12 & Culture Centre & Yes & No \\
\hline 5 & Building 13 & Residential & Yes & No \\
\hline “ & Building 14 & Sports Centre & Yes & No \\
\hline “ & Building 15 & Public school & Yes & No \\
\hline “ & Building 16 & Residential & Yes & No \\
\hline “ & Building 17 & Residential & Yes & No \\
\hline “ & Building 18 & Public kindergarten & Yes & No \\
\hline “ & Building 19 & Public school & Yes & No \\
\hline
\end{tabular}

Source: Author

From the above data the following Extensible Markup Language (XML) files have been created for parsing to the VPP engine:

- CityModel.xml

- Commodities.xml

- Run.xml

- $\quad$ Timeseries.xml

Electricity network topology has been input into the CityModel.xml. Meter readings from the SCDB-CDSS, formatted within Excel, have been input into the Timeseries.xml. The Commodities.xml defines commodity attributes such as $\mathrm{CO}^{2}$ emission factors. Run.xml defines the VPP run specifier settings such as start / end date and time. 
'What if' - scenarios

Table 2 outlines selected DER installations for prosumer objects (buildings 1 to 19) and utility objects (substations 1 to 5) across 8 scenarios.

Table 2. Scenario parameters

\begin{tabular}{|c|c|c|c|c|c|c|c|c|c|c|}
\hline & $\stackrel{\overrightarrow{0}}{\overrightarrow{0} 0}$ & 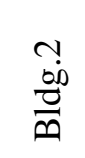 & $\begin{array}{cc}\vdots & \\
\dot{r}_{1} & \sigma^{0} \\
\dot{m}\end{array}$ & $\begin{array}{l}\stackrel{\infty}{\rightarrow} \\
\stackrel{\infty}{0} \\
\frac{0}{\infty}\end{array}$ & $\begin{array}{l}\frac{\sigma}{0} \\
\frac{00}{00}\end{array}$ & 当 & 官 & 尚 & 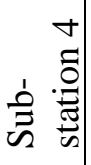 & 官 \\
\hline \multicolumn{11}{|l|}{ Scenario 1} \\
\hline $\mathrm{PV}(\mathrm{kW})$ & 1 & 1 & 1 & 1 & 1 & - & - & - & - & - \\
\hline \multicolumn{11}{|l|}{ Scenario 2} \\
\hline $\mathrm{PV}(\mathrm{kW})$ & 6 & 6 & 6 & 6 & 6 & - & - & - & - & - \\
\hline \multicolumn{11}{|l|}{ Scenario 3} \\
\hline Wind $(\mathrm{kW})$ & 1.5 & 1.5 & 1.5 & 1.5 & 1.5 & - & - & - & - & - \\
\hline \multicolumn{11}{|l|}{ Scenario 4} \\
\hline Wind $(\mathrm{kW})$ & 15 & 15 & 15 & 15 & 15 & - & - & - & - & - \\
\hline \multicolumn{11}{|l|}{ Scenario 5} \\
\hline PV $(\mathrm{kW})$ & 1 & 1 & 1 & 1 & 1 & - & - & - & - & - \\
\hline Energy storage (kWh) & 50 & 50 & 50 & 50 & 50 & - & - & - & - & - \\
\hline \multicolumn{11}{|l|}{ Scenario 6} \\
\hline PV $(\mathrm{kW})$ & 6 & 6 & 6 & 6 & 6 & - & - & - & - & - \\
\hline Energy storage (kWh) & 50 & 50 & 50 & 50 & 50 & - & - & - & - & - \\
\hline \multicolumn{11}{|l|}{ Scenario 7} \\
\hline Wind $(\mathrm{kW})$ & 1.5 & 1.5 & 1.5 & 1.5 & 1.5 & - & - & - & - & - \\
\hline $\begin{array}{l}\text { Energy storage (kWh) } \\
\end{array}$ & 50 & 50 & 50 & 50 & 50 & - & - & - & - & - \\
\hline \multicolumn{11}{|l|}{ Scenario 8} \\
\hline Wind $(\mathrm{kW})$ & 15 & 15 & 15 & 15 & 15 & - & - & - & - & - \\
\hline Energy storage (kWh) & 50 & 50 & 50 & 50 & 50 & - & - & - & - & - \\
\hline
\end{tabular}

Source: Author

DER installation parameters are shown in Table 3 to Table 5, installation types refer to the number shown in Table 2. For example, scenario 1 includes a 1No. 1kW (small domestic) PV panel assigned individually to all 19 buildings, sub-stations have not been assigned DER installations. Whereas scenario 5 includes 1 No. $1 \mathrm{~kW}$ PV panel and 1No. 50kWh energy storage device assigned individually to all 19 buildings and so on.

Table 3. PV array parameters

\begin{tabular}{|l|c|c|c|c|c|}
\hline Installation category & Area $\left(\mathrm{m}^{2}\right)$ & $\begin{array}{c}\text { Azimuth } \\
\left({ }^{0} \text { clockwise }\right. \\
\text { from north) }\end{array}$ & $\begin{array}{c}\text { Inclination } \\
\left({ }^{\circ} \text { from }\right. \\
\text { horizontal })\end{array}$ & $\begin{array}{c}\text { PV module } \\
\text { nominal } \\
\text { efficiency }\end{array}$ & $\begin{array}{c}\text { Nominal cell } \\
\text { temperature } \\
(\text { NOCT })\left({ }^{\circ} \mathrm{C}\right)\end{array}$ \\
\hline $\begin{array}{l}\text { PV 1kW } \\
\text { (small domestic) }\end{array}$ & 7.2 & 180 & 35 & 0.1100 & 45.0 \\
\hline
\end{tabular}




\begin{tabular}{|l|c|c|c|c|c|}
\hline $\begin{array}{l}\text { PV 6kW } \\
\text { (large domestic) }\end{array}$ & 43.2 & 180 & 35 & 0.1100 & 45.0 \\
\hline
\end{tabular}

\begin{tabular}{|c|c|c|c|c|}
\hline $\begin{array}{c}\text { Reference } \\
\text { irradiance for } \\
\text { NOCT }(\mathrm{W} / \mathrm{m} 2)\end{array}$ & $\begin{array}{c}\text { Temp. coefficient for } \\
\text { module efficiency } \\
(1 / \mathrm{K})\end{array}$ & $\begin{array}{c}\text { Degradation } \\
\text { factor }\end{array}$ & $\begin{array}{c}\text { Shading } \\
\text { factor }\end{array}$ & $\begin{array}{c}\text { Electrical } \\
\text { conversion }\end{array}$ \\
\hline 800 & 0.0040 & 0.99 & 1.0 & 0.85 \\
\hline 800 & 0.0040 & 0.99 & 1.0 & 0.85 \\
\hline
\end{tabular}

Source: Author

Table 4. Wind turbine parameters

\begin{tabular}{|l|c|c|c|}
\hline \multicolumn{1}{|c|}{ Installation category } & $\begin{array}{c}\text { Rated power } \\
(\mathrm{kW})\end{array}$ & $\begin{array}{c}\text { Hub height } \\
(\mathrm{m})\end{array}$ & $\begin{array}{c}\text { Power curve } \\
\text { [wind speed (m/s), Power } \\
\text { output fraction \%] }\end{array}$ \\
\hline Wind 1.5kW (house) & 1.5 & 5 & 0040.170 .5120 .8251 \\
\hline Wind 15kW (farm) & 15 & 5 & 0040.170 .5120 .8251 \\
\hline
\end{tabular}

Source: Author

Table 5. Electrical energy storage parameters

\begin{tabular}{|l|c|c|c|c|}
\hline \multicolumn{1}{|c|}{ Installation category } & $\begin{array}{c}\text { Storage } \\
\text { Capacity } \\
(\mathrm{kWh})\end{array}$ & $\begin{array}{c}\text { Initial storage } \\
\text { energy }(\mathrm{kWh})\end{array}$ & Storage Method & Losses \\
\hline $\begin{array}{l}\text { lithium-ion Battery } \\
50 \mathrm{kWh}\end{array}$ & 50 & 2 & lithium-ion Battery & 0 \\
\hline
\end{tabular}

Source: Author

\section{Results}

Rijeka case study VPP results for 'as is' and 'what if' scenarios, discussed in the above sections, are shown in Table 6 . Table 6 results are presented for the electricity commodity account, i.e. root node, not for each electricity node in the network.

Based on the selected 'what if' scenarios the results reflect the expected behaviour of the electricity network for scenarios 1 to 8 when compared against the 'as is' scenario i.e. the baseline scenario. Where renewables have been introduced, PVs and wind turbines only for scenarios 1 to 4, demand from external supply to the network has reduced. This is a result of renewables offsetting electricity demand from buildings 1 to 19. This also results in a reduction in $\mathrm{CO}^{2}$ emissions within the model based on the reduction of fossil fuel based external supply to the network. There is a noticeable difference between the PV and wind turbine scenario results. This difference is due to the variation in wind speed for Rijeka based on its coastal location; average, maximum and minimum wind speed for the selected period of analysis is $3.44 \mathrm{~m} / \mathrm{s}, 10.19 \mathrm{~m} / \mathrm{s}$ and $0.89 \mathrm{~m} / \mathrm{s}$. Also scenario 4 is based on a $15 \mathrm{~kW}$ wind turbine. This may be considered unrealistic but it gives an indication of electricity generation range from 1.5 to $15 \mathrm{~kW}$ installations. 
In scenarios 5 to 8, which include electricity storage in addition to selected renewable technology, external supply and carbon emission reduce when compared to scenarios 1 to 4 with no electricity storage installations. This is a result of model set-up where electricity storage devices have been applied at building level. In some cases on-site electricity generation from renewables at building level exceeds electricity building level demands. In this case excess electricity generation charges on-site storage prior to being fed back to the electricity network upon electricity storage equalling storage capacity. In other instances electricity demand at building level exceeds onsite electricity generation. This results in an electricity residual demand from the electricity network, sub-station and then parent node, which in turn equates to an increase in external supply and $\mathrm{CO}^{2}$ emissions to the model. This could be adverted with better electricity storage controls and storage at sub-station level. Future scenarios will look to address this.

Table 6. Rijeka VPP results, percentage difference against ‘as is’ baseline model

\begin{tabular}{|l|c|c|}
\hline \multicolumn{1}{|c|}{ Scenario } & $\begin{array}{c}\text { External } \\
\text { supply } \\
\text { (\% diff) }\end{array}$ & $\begin{array}{c}\text { External indirect } \mathbf{C O}^{2} \\
\text { emission } \\
\text { (\% diff) }\end{array}$ \\
\hline as-is (baseline model) & - & - \\
\hline Scenario 1 - 1kW PV & $0.30 \%$ & $0.30 \%$ \\
\hline Scenario 2 - 6kW PV & $1.75 \%$ & $1.67 \%$ \\
\hline Scenario 3 - 1.5kW Wind turbine & $0.78 \%$ & $0.77 \%$ \\
\hline Scenario 4 - 15kW Wind turbine & $7.40 \%$ & $7.30 \%$ \\
\hline Scenario 5 - 1kW PV and 50kWh storage & $0.31 \%$ & $0.31 \%$ \\
\hline Scenario 6 - 6kW PV and 50kWh storage & $1.45 \%$ & $1.39 \%$ \\
\hline Scenario 7 - 1.5kW Wind turbine and 50kWh storage & $0.73 \%$ & $0.73 \%$ \\
\hline Scenario 8 - 15kW Wind turbine and 50kWh storage & $5.64 \%$ & $5.58 \%$ \\
\hline
\end{tabular}

Source: Author

\section{Conclusions}

The VPP tool developed in iURBAN is considered a prototype since there is a small set of available data from iURBAN demo cities, refer to case study description. With this in mind the CDSS-GUI and the VPP provide means to scale up metered demands using multiplier factors so that they sum to realistic values at the district and city levels.

The VPP has been developed in a way that is scalable and repeatable. However, like most simulation tools data is critical to the inputs and outputs of the tool. As discussed within the case study example a simple network model can only be constructed unless there is sufficient information on the network topologies and access to a wide range of metered data. In response to the lack of metered data the VPP has been developed to receive both metered and simulated data. The IES Virtual Environment (IES-VE) (IES Ltd, 2016) is a building modelling tool capable of generating building related energy demands and generation in Timeseries format. Energy profiles could be produced from a range of IES $\angle \mathrm{VE}>$ building models and the outputs fed into the VPP. This is outside the scope of the iURBAN project.

Future work to consist of refining the Rijeka case study based on detailed electricity network topology. Other work to include the modelling of the second iURBAN case study in Plovdiv, Bulgaria. This work is to take place 
from July onwards as part of the iURBAN ICT tools evaluation and validation period, upon the integration of the CDSS and VPP.

Future VPP development to include district cooling, water networks and optimised control strategies.

\section{References}

Asmus, P. 2014. How Real are Virtual Power Plants?. [ONLINE] Available at:

http://www.elp.com/articles/powergrid_international/print/volume-19/issue-11/features/how-real-are-virtual-power-plants.html [Accessed 24 May 2016].

GridLAB-D. 2012. GridLAB-D. [ONLINE] Available at: http://www.gridlabd.org/ [Accessed 24 May 2016].

IES Ltd. 2016. Integrated Environmental Solutions. [ONLINE] Available at: https://www.iesve.com/ [Accessed 24 May 2016].

iURBAN. 2016. iURBAN. [ONLINE] Available at: http://www.iURBAN-project.eu/ [Accessed 24 May 2016].

Landsbergen, P. 2009. Feasibility, beneficiality, and institutional compatibility of a micro-CHP virtual power plant in the Netherlands. Maters Thesis. Published by TU Delft. http://repository.tudelft.nl/view/ir/uuid\%3Aee01fc77-2d91-43bb-83d3-847e787494af/

Mostafa, N.; Rahmat-Allah,H.; Eskandar, G. 2017. A comprehensive review on microgrid and virtual power plant concepts employed for distributed energy resources scheduling in power systems. Renewable and Sustainable Energy Reviews, 67, 341-363 DOI: http://dx.doi.org/10.1016/j.rser.2016.09.025

Navigant Research. 2014. Virtual Power Plants. [ONLINE] Available at: http://www.navigantresearch.com/research/virtual-power-plants [Accessed 24 May 2016].

Othman, M.; Hegazy, Y.; Abdelaziz, A. 2015. A Review of Virtual power plant Definitions, Components, Framework and Optimization, International Electrical Engineering Journal (IEEJ) 6 (9): 2010-2024 DOI: http://www.ieejournal.com/2015/a-review-of-virtual-powerplant-definitions-components-framework-and-optimization/

Vitrociset. 2016. Vitrociset. [ONLINE] Available at: http://www.vitrociset.it/index.php?lang=en [Accessed 24 May 2016].

Weather Analytics. 2016. Weather Analytics. [ONLINE] Available at: http://www.weatheranalytics.com/wa/ [Accessed 24 May 2016].

\section{Acknowledgements}

This research was supported by the iURBAN project. Project funding from the European Union's Seventh Programme for research, technological development and demonstration under grant agreement No 608712

The article reflects the views only of the authors, and the Commission cannot be held responsible for any use which may be made of the information contained therein. The information in this document is provided as is and no guarantee or warranty is given that the information is fit for any particular purpose. The user thereof uses the information at its sole risk and liability 


\section{The International Journal
ENTREPRENEURSHIP AND SUSTAINABILITY ISSUES}

ISSN 2345-0282 (online) http://jssidoi.org/jesi/

2017 Volume 4 Number 3 (March)

\section{Authors}

Michael OATES PhD, is technical analyst on commercial, and research and development (R\&D) projects. Working for IES for over 3 years Michael has been technical lead /analyst on 6 European projects, FP7, H2020, and Marie Curie etc., http://www.iesve.com/research. Research project topic areas included glazing (electrochromic glazing), retrofit technologies, manufacturing, city modelling, and application development including gamification.

ORCID ID: 0000-0003-1339-0848

Aidan MELIA is a project manager working on commercial and research and development (R\&D) projects. Working for IES for over 3 years Aidan has managed 3 European projects, such as FP7 and H2020. These focus on the areas of smart cities and ICT developments, as well as more recently focusing on areas such as gamification. He has studied in a number of countries such as Ireland, the US, Spain and Germany.

ORCID ID: 0000-0001-5498-4576

Valeria FERRANDO PhD, is EU Head of Research. In 2013 Valeria joined the Research and Development (R\&D) division of IES Ltd where she deals with EU funded research, managing projects ensuring that they lead to marketable products for the company and finding new funding opportunities and research grants at European level to support IES R\&D, setting up partnerships and writing proposals.

ORCID ID: 0000-0003-2296-7346

Copyright (C 2016 by author(s) and VsI Entrepreneurship and Sustainability Center

This work is licensed under the Creative Commons Attribution International License (CC BY). http://creativecommons.org/licenses/by/4.0/

cC) (i) Open Access 